\title{
WATER RELATIONS OF FIELD-GROWN GRAPEVINES IN THE SÃO FRANCISCO VALLEY, BRAZIL, UNDER DIFFERENT ROOTSTOCKS AND IRRIGATION STRATEGIES
}

\author{
Claudia Rita de Souza ${ }^{1}$; Luís Henrique Bassoi ${ }^{2 *}$; José Moacir Pinheiro Lima Filho²; Fabrício \\ Francisco Santos da Silva²; Leandro Hespanhol Viana ${ }^{3}$; Barbara França Dantas²; Maiane \\ Santos Pereira ${ }^{2}$; Paula Rose de Almeida Ribeiro ${ }^{2}$ \\ ${ }^{1}$ IAPAR, C.P. 481 - 86047-902 - Londrina, PR - Brasil. \\ ${ }^{2}$ Embrapa Semi-Árido - C.P. 23 - 56302-970 - Petrolina, PE - Brasil. \\ ${ }^{3}$ UENF/CCTA - Av. Alberto Lamego, 2000 - 28013-600 - Campos dos Goytacases, RJ - Brasil. \\ *Corresponding author <lhbassoi@cpatsa.embrapa.br>
}

\begin{abstract}
There is an increased demand for high quality winegrapes in the São Francisco Valley, a new wine producing area in Brazil. As the grape quality is closely linked to the soil water status, understanding the effects of rootstock and irrigation management on grapevine water relations is essential to optimize yield and quality. This study was carried out to investigate the effects of irrigation strategies and rootstocks on water relations and scion vigour of field-grown grapevines in Petrolina, Pernambuco state, Brazil. The cultivars used as scions are Moscato Canelli and Syrah, both grafted onto IAC 572 and 1103 Paulsen rootstocks. The following water treatments were used: deficit irrigation, with holding water after veraison; and partial root-zone drying, supplying (100\% of crop evapotranspiration) of the water loss to only one side of the root system after fruit set, alternating the sides periodically (about 24 days). In general, all treatments had values of pre-dawn leaf water potential higher than $-0.2 \mathrm{MPa}$, suggesting absence of water stress. The vine water status was more affected by rootstock type than irrigation strategies. Both cultivars grafted on IAC 572 had the highest values of midday leaf water potential and stem water potential, measured on non-transpiring leaves, which were bagged with both plastic sheet and aluminum foil at least $1 \mathrm{~h}$ before measurements. For both cultivars, the stomatal conductance $\left(g_{s}\right)$, transpiration $(E)$ and leaf area index (LAI) were also more affected by roostsotck type than by irrigation strategies. The IAC 572 rootstock presented higher $g_{s}$, $E$ and LAI than the 1103 Paulsen. Differences in vegetative vigor of the scion grafted onto IAC 572 rootstocks were related to its higher leaf specific hydraulic conductance and deeper root system as compared to the 1103 Paulsen, which increased the water-extraction capability, resulting in a better vine water status.

Key words: Vitis vinifera L., partial rootzone drying, deficit irrigation, stomatal conductance

\section{RELAÇÕES HIIDRICAS DE VIDEIRAS CULTIVADAS NO VALE DO SÃO FRANCISCO SOB DIFERENTES PORTA-ENXERTOS E ESTRATÉGIAS DE IRRIGAÇÃO}

\begin{abstract}
RESUMO: Existe aumento na demanda por vinhos de alta qualidade no Vale do São Francisco, nova região produtora de vinhos no Brasil. Como a qualidade da uva depende do estado hídrico da videira, o conhecimento dos efeitos do porta-enxerto e do manejo de irrigação sobre as relações hídricas da videira é essencial para otimizar a produção e qualidade da uva. Sendo assim, avaliou-se a influência de porta-enxertos e estratégias de irrigação sobre as relações hídricas e o vigor vegetativo de videiras cultivadas em Petrolina, PE. Duas variedades copa, 'Moscato Canelli' e 'Syrah', enxertadas sobre IAC 572 e 1103 Paulsen foram submetidas a duas estratégias de irrigação: irrigação com deficit, na qual a irrigação foi suspensa após o início da maturação; e irrigação parcial das raízes, em que a água foi aplicada (100\% da evapotranspiração da cultura) após o pegamento dos frutos, em apenas metade do sistema radicular, alternando os lados periodicamente ( 24 dias). Em geral, todos os tratamentos apresentaram valores de potencial hídrico foliar de base superiores a -0,2 $\mathrm{MPa}$, indicando ausência de estresse hídrico. O estado hídrico da videira foi mais afetado pela porta-enxerto que pelos tratamentos hídricos. Os dois cultivares enxertadas sobre o IAC 572 apresentaram os maiores valores de potencial
\end{abstract}


hídrico foliar, medido ao meio dia, e de potencial hídrico do caule, medido em folhas 1 hora após o acondicionamento em saco plástico e papel alumínio. Nos dois cultivares, a condutância estomática $(g)$, transpiração $(E)$ e índice de área foliar (IAF) foram mais afetados pelos porta-enxertos que pelos tratamentos de irrigação. Os cultivares enxertados sobre IAC 572 apresentaram maiores $g_{s}, E$ e IAF em relação às enxertadas sobre o 1103 Paulsen. O elevado vigor vegetativo das cultivares foi provavelmente devido ao efeito do IAC 572 sobre a condutividade hidráulica das folhas e à maior absorção de água pelo sistema radicular deste porta-enxerto.

Palavras-chave: Vitis vinifera L., irrigação parcial das raízes, irrigação com deficit, condutância estomática

\section{INTRODUCTION}

There is an increasing demand for high-quality wine by wine producers in the São Francisco Valley, Brazil, considered a new region for grape crops for wine production under tropical conditions. The challenge facing winemakers is to improve grape quality in irrigated vineyards throughout an appropriate balance between vegetative and reproductive developments since an excess of shoot vigour contributes to a high canopy density leading to high water loss, fungal diseases, shading of grape clusters, which may negatively affect fruit compositions (Jackson \& Lombard, 1993).

In the New World vineyards, particularly, much effort has been spent on developing deficit irrigation strategies to control vegetative vigor, such as regulated deficit irrigation (RDI), where the water input is either reduced or withhold for specific phenological periods, or partial rootzone drying (PRD), where the water is only applied to one side to the root system, while the remainder is left to dry; or deficit irrigation (DI) where less than full ETo replacement is applied during the entire growing season in vineyards (McCarthy, 1997; Loveys et al., 2000; Santos et al., 2003; Souza et al., 2003).

Rootstocks have also been used to manipulate canopy physiology, and thus, yield and fruit quality, since they vary in root distribution, nutrient absorption, and vessel morphology, which affect vigor, yield, grape and wine quality (Koblet et al., 1994; Morano \& Kliwer, 1994; Ferroni \& Scalabrelli, 1995; Gonçalves, 1996; Kaserer et al., 1996; Pauletto et al., 2001a,b; Main et al., 2002; Terra et al., 2003; Paranychianakis et al., 2004). Rootstocks also have effects on water relations and gas exchanges of grapevine scions (Scienza et al., 1980; Carbonneau, 1985; Koblet et al., 1997; Iacono et al., 1998; Herralde et al., 2006, Toumi et al., 2007). In this context, the aim of this study was to investigate the effects of rootstocks and water management on water relations of grapevines growing under semi-arid conditions in Northeast Brazil, since little knowledge on these subjects is available for that region.

\section{MATERIAL AND METHODS}

\section{Field conditions and plant material}

The experiment was carried out from August to November of 2005, in Petrolina, Pernambuco State, Brazil (0909' S, 4022' W, $365.5 \mathrm{~m}$ above sea level). The semi-arid regional climate is classified as BSh according to Köeppen. The average annual rainfall is 567 $\mathrm{mm}$ (30 years series mean), with $510 \mathrm{~mm}$ falling from November to April (Teixeira, 2001). During the experimental period, the local weather conditions (temperature, global radiation, vapour pressure deficit and reference evapotranspiration) were recorded by means of an automated weather station, located $50 \mathrm{~m}$ from the vineyard. The soil is classified as a medium-textured Typic Acrustox, or according to the Brazilian Soil Classification System (Embrapa, 1999), as an Argissolo Vermelho Amarelo Eutrófico Latossólico, with fragipan, (Silva, 2005). The two selected wine grape scion varieties of Vitis vinifera L studied were Moscato Canelli and Syrah, both grafted on IAC 572 and 1103 Paulsen, planted in September 2002. The 3 years old grapevines were spaced $3.0 \mathrm{~m}$ between rows and $1.5 \mathrm{~m}$ between stocks. Vines were trained on a bilateral Royat Cordon and spur-pruned in the first of August, 2005. Standard cultural practices in the region were applied to all treatments during the growing season.

\section{Irrigation and experimental design}

Water was applied by drip irrigation (emitter flow of $4.3 \mathrm{~L} \mathrm{~h}^{-1}$ ), and the wetted area was $33 \%$, determined as recommended by Keller \& Bliesner (2000). For the PRD treatment, two drip lines per plant row were installed, one at each side of the trunk, with drippers spaced $1.5 \mathrm{~m}$ in the same line, and arranged to set two emitters per plant, one in each drip line. The trunk side to be irrigated was controlled by valves installed on the drip lines. For the DI treatment, only one drip line per plant row was installed, with three emitters per vine, spaced $0.5 \mathrm{~m}$. Consequently, to apply the same amount of water to both treatments, the irrigation time was different. The irrigation scheduling was performed using daily ETo $\left(\mathrm{mm} \mathrm{day}^{-1}\right)$ and crop coefficient $(\mathrm{Kc})$ values for winegrapes in São Francisco Valley (0.7 - pruning to bud burst; 1.0 - bud 
burst to bloom; 1.0 - bloom to fruit set; 0.8 - fruit set to berry ripening; and 0.4 - berry ripening to harvest), as reported by Silva (2005). For PRD, the water was applied to both trunk sides until 49 days after pruning (dap), and the alternation of trunk side to be irrigated started at 50 dap (July $7^{\text {th }}$ ) after fruit set. Two other alternations occured on 73 (October $12^{\text {th }}$ ) and 98 dap (November $6^{\text {th }}$ ), whereas for DI the water was withhold on 92 dap (October $31^{\text {st }}$ ) after veraison (beginning of berry ripening). For both cultivars, the total water applied (L per plant) was 2130 for DI and 2266 for PRD until 109 dap. Harvest was performed in November $21^{\text {st }}, 2005$ (112 dap) for Moscato Canelli and in November $29^{\text {th }}, 2005$ (120 dap) for Syrah. Soil water content $\left(\theta, \mathrm{m}^{3} \mathrm{~m}^{-3}\right)$ was measured at $0.2,0.4,0.6$, $0.8,1.0$, and $1.2 \mathrm{~m}$ depths in all treatments, with 3 replications, by the neutron scattering technique. The probe was previously calibrated at the same site. Experimental design for both cultivars consisted of a randomised block design with two factors (irrigation and rootstock), with five replications. In each block, irrigation treatments and rootstocks were randomized. Each block, with six rows and 18 plants per row, was divided into four plots, two set in front of the other two plots. In each plot (three rows, nine plants in each row), only the center row with six plants was used for data collection.

\section{Grapevine water relations, stomatal resistance and growth measurements}

The vine water status was evaluated by measurements of pre-dawn leaf water potential $\left(\Psi_{\mathrm{pd}}\right)$, midday leaf water potential $\left(\Psi_{\mathrm{md}}\right)$ and stem water potential $\left(\Psi_{\text {stem }}\right)$, measured weekly with a Scholander-type pressure chamber. For both cultivars, the $\Psi_{\mathrm{pd}}$ was measured before sunrise, the $\Psi_{\mathrm{md}}$ was measured between $01 \mathrm{~h} 00$ to $03 \mathrm{~h} 00 \mathrm{p} . \mathrm{m}$. and $\Psi_{\text {stem }}^{\text {md }}$ was measured around $10 \mathrm{~h} 00$ a.m. Measurements were taken on six fully expanded and well-exposed leaves per treatment after fruit set until harvest. The $\Psi_{\text {stem }}$ was measured on non-transpiring leaves, that had been bagged with both plastic sheet and aluminum foil for at least $1 \mathrm{~h}$ before measurements. The leaf water potential was considered to be equal to stem water potential when leaf transpiration is prevented (Choné et al., 2001).

Leaf transpiration $(E)$ and stomatal resistance $\left(r_{s}\right)$ measurements were taken on mature, well-exposed leaves located in the middle of the main shoot with a steady state porometer. The measurements were performed on six leaves per treatment during afternoon ( $01 \mathrm{~h} 00$ to $03 \mathrm{~h} 00$ p.m.). The values of $r_{s}\left(\mathrm{~s} \mathrm{~cm}^{-1}\right)$ were converted to $\mathrm{g}_{\mathrm{s}}\left(\mathrm{mol} \mathrm{m} \mathrm{m}^{-2} \mathrm{~s}^{-1}\right)$ using the formula $g_{s}=\frac{1}{r_{s}} \times 2.5$, and the units of $E$ were converted from ug $\mathrm{cm}^{-2} \mathrm{~s}^{-1}$ to $\mathrm{mmol} \mathrm{m} \mathrm{m}^{-2}$ by by means of the formula: $m o l m^{-2} s^{-1}=\frac{m g m^{-2} s^{-1}}{18000}$, both formulas provided by the porometer manufacturer. Leaf specific hydraulic conductance $\left(\mathrm{K}_{\text {leaf }}\right.$ mmol $\left.\mathrm{MPa} \mathrm{m}^{-2} \mathrm{~s}^{-1}\right)$ was calculated as $K_{\text {leaf }}=\frac{E}{\Psi_{m d}-\Psi_{p d}}$ (Shultz, 2003). The transpiration was measured on the same leaves used for leaf water potential measurements.

The influence of rootstock on leaf area development was evaluated by the leaf area index (LAI) using a plant canopy analyzer as suggested by Lima Filho et al. (2006) for vertical shoot positioning trellis system vineyards. Within vineyards, the values from LAI measurements can be used to support canopy and irrigation management decisions affecting grape quality and yield (Ollat et al., 1998; Johnson \& Pierce, 2004). The basic technique combines a measurement of sky brightness from a leveled sensor set up above canopy with a second measurement taken beneath the canopy (Welles \& Norman, 1991). Due to the trellis system used in this study, the reference was taken with the sensor facing a white-painted panel to mimic sky diffuse radiation since direct sky radiation may underestimate LAI. The panel was then placed just behind the vine canopy for subsequent measurements and LAI calculations made by the plant canopy analyzer. Data collection was initiated early in the morning, about 09h00 a.m., to avoid radiation striking on the sensor. Five plants per treatment were used for LAI determinations. Results of physiological measurements shown in this paper corresponded to the ripening period (November), in which both irrigation treatments were compared. Measurements of $\Psi_{\mathrm{pd}}, \Psi_{\mathrm{md}}, \Psi_{\text {stem }}, g_{s}, E$ and LAI were performed in two blocks, where three plants (one leaf per plant) in each block were sampled, totalizing six replicates per treatment.

\section{Statistical analyses}

Data sets were subjected to analyses of variance (ANOVA) with irrigation and rootstock as main factors. Tukey HSD tests were carried out to determine differences between treatment means, using the STATISTICA software (ver. 5.0, Statsoft, Inc. Tulsa, OK, USA)

\section{RESULTS AND DISCUSSION}

For both scion / rootstock combinations under both irrigation strategies, the most significant changes in $\theta$ were found for the $0.2,0.4$ and $0.6 \mathrm{~m}$ depths and, consequently, lowest $\theta$ values were found in these upper soil layers. The $\theta$ decrease in the non irrigated trunk 
side initiated immediately after the PRD beginning (50 dap) and PRD alternations (73 and 98 dap), as well as the $\theta$ increase in the irrigated trunk side. The same behavior happened with DI, i.e., $\theta$ decreased after irrigation interruption (93 dap). Figure 1 shows the $\theta$ behavior for the PRD and DI treatments and for the Syrah grafted on IAC 572, and is representative for the $\theta$ behavior observed in all treatments. The presence of a fragipan in this soil (Silva, 2005) makes its drainage slower at greater depths. Pedological surveys
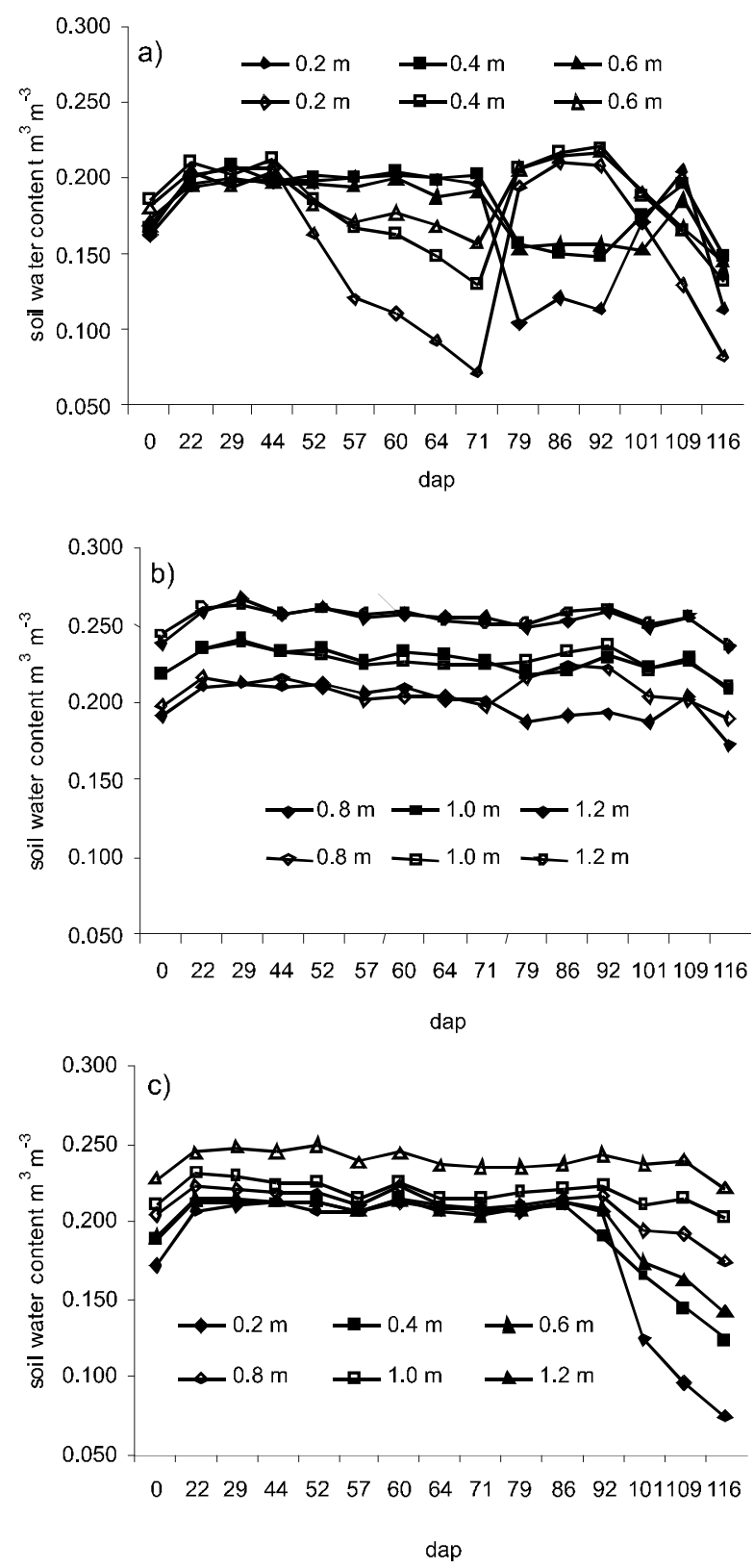

Figure 1 - Soil water content in the soil cultivated with grapevine Syrah grafted on rootstock IAC 572: (a) at 0.2, 0.4, and $0.6 \mathrm{~m}$ depths, in partial rootzone drying (PRD) treatment; (b) at the 0.8, 1.0, and $1.2 \mathrm{~m}$ depths, for the PRD treatment; (c) at all soil depths for the deficit irrigation (DI) treatment. (dap = days after pruning). carried out in the São Francisco Valley have shown an expressive occurrence of soils with subsurface hardsetting that can restrict water distribution to the deeper portions of soil profile (Silva, 2000).

The slight reduction in soil water availability at 0.8 , 1.0 , and $1.2 \mathrm{~m}$ soil depths was reflected by the $\Psi$ (Figure 2). Values among treatments ranged from -0.08 to $-0.16 \mathrm{MPa}$ during the evaluated period. Only for Syrah the vines grafted onto 1103 Paulsen presented significant differences $(p<0.05)$ between irrigation treatments near to harvest, with $\Psi_{\mathrm{pd}}$ of PRD being higher than for DI vines (Figures $2 \mathrm{c}, \mathrm{d}, \mathrm{g}, \mathrm{h}$ ). Regarding rootstock effects, the greatest differences were observed for the cultivar Moscato Canelli, with the IAC 572 rootstock showing higher $\Psi_{\text {pd }}$ than 1103 Paulsen for both irrigation treatments (Figures $2 \mathrm{a}, \mathrm{b}$, e, f).

Although the small range of $\Psi_{\mathrm{pd}}$, the leaf water status measured by midday leaf water potential $\left(\Psi_{\text {md }}\right)$ was affected by water treatments (Figure 3). For Syrah, the $\Psi_{m d}$ of vines grafted onto 1103 Paulsen was lower for PRD than DI vines at November $9^{\text {th }}$ (Figure $3 \mathrm{c}$ ). However, at the end of experimental period, the value of PRD was higher than DI. There was a significant interaction between rootstock and irrigation for Moscato Canelli. Only under PRD conditions there were differences between rootstocks, with vines grafted onto IAC 572 keeping the leaf water status higher than that of 1103 Paulsen (Figures 3 e, f). The $\Psi_{\text {md }}$ was lower for DI than for PRD only for grapevines grafted onto IAC 572 (Figures $3 \mathrm{~g}$, h).

The $\Psi_{\text {stem }}$ also allowed a clear differentiation between the treatments. For Syrah, the grapevines grafted onto IAC 572 showed high values of $\Psi_{\text {stem }}$ in both irrigation treatments (Figures $4 \mathrm{a}, \mathrm{b}$ ). However, there was no difference between PRD and DI vines grafted onto both rootstocks (Figures $4 \mathrm{c}$, d). For Moscato Canelli, the greatest differences between rootstock were observed under the PRD strategy, and IAC 572 had the highest values of $\Psi_{\text {stem }}$ (Figures 4 e, f). The differences between irrigation strategies were only observed for grapevines grafted onto IAC 572, for which $\Psi_{\text {stem }}$ of PRD vines was higher than of DI vines (Figures $4 \mathrm{~g}, \mathrm{~h}$ ).

Reduction in stomatal aperture due to the abscisic acid synthesized in the drying roots may have contributed to avoid water loss and keep the leaf water status of PRD vines (Stoll et al., 2000, Souza et al., 2003). Moreover, during the growing season (112 days for Moscato Canelli and 120 days for Syrah), the total of water applied to PRD was slightly higher (2266 L per plant) than to DI vines ( $2130 \mathrm{~L}$ per plant). This fact may have contributed to keep the high leaf water status of grapevines under PRD conditions. 


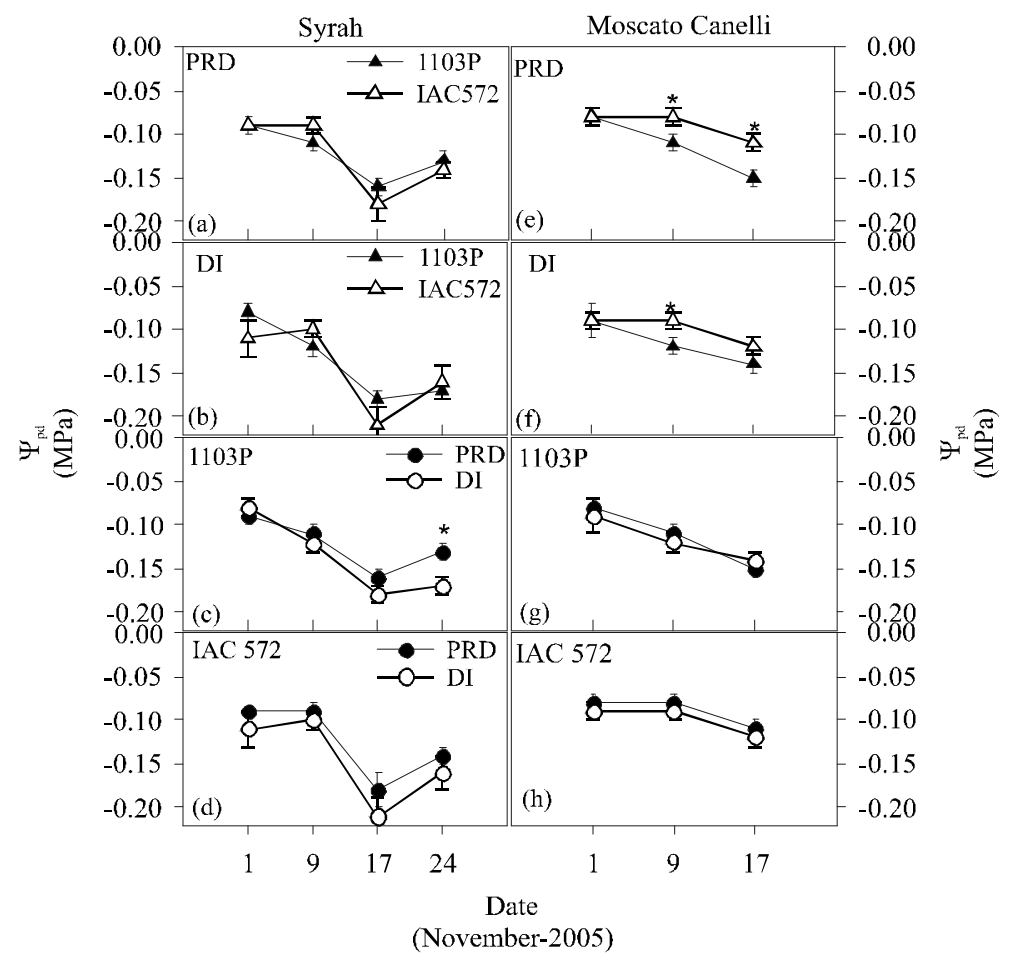

Figure 2 - Leaf water potential at pre-dawn $\left(\Psi_{\mathrm{pd}}\right)$ for rootstocks and irrigation treatments for Syrah (a, b, c, d) and Moscatel (e, f, g, h) grapevines. Values of $\Psi_{\mathrm{pd}}$ are means \pm SE. Asterisks mean differences $(p<0.05)$. $(\mathrm{PRD}=$ partial rootzone drying; DI $=$ deficit irrigation).

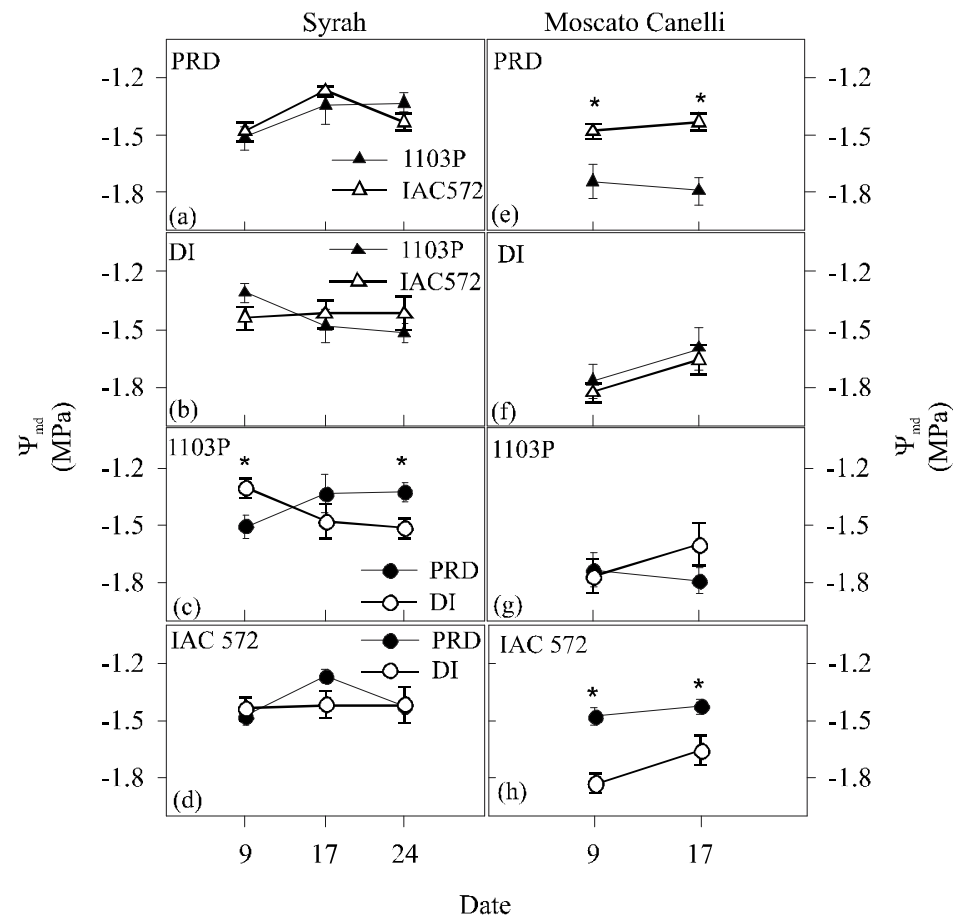

(November-2005)

Figure 3 - Midday leaf water potencial $\left(\Psi_{\mathrm{md}}\right)$ for rootstocks and irrigation treatments for Syrah (a, b, c, d) and Moscato Canelli (e, f, g, h) grapevines. Values of leaf $\Psi_{\mathrm{md}}^{\mathrm{md}}$ are means \pm SE. Asterisks mean differences $(p<0.05)$. (PRD = partial rootzone drying; DI $=$ deficit irrigation). 


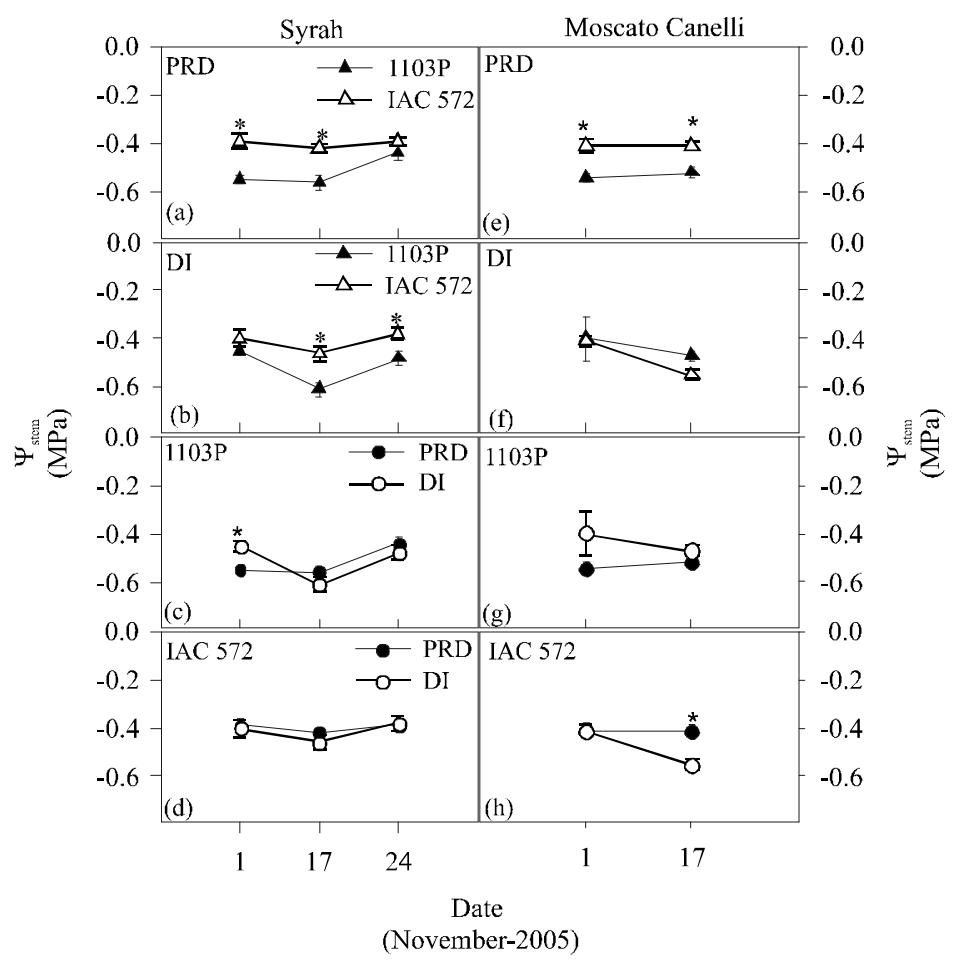

Figure 4 - Effects of rootstock and irrigation treatment on stem water potential $\left(\Psi_{\text {stem }}\right)$ of Syrah (a, b, c, d) and Moscato Canelli (e, f, g, h) grapevines. Values of stem water potential are means \pm SE. Asterisks mean differences $(p<0.05)$. (PRD = partial rootzone drying; DI = deficit irrigation).

The effects of irrigation and rootstock were more discriminated by $\Psi_{\text {stem }}$ and $\Psi_{\text {md }}$ than by $\Psi_{\text {pd }}$. It is often assumed that $\Psi_{\mathrm{pd}}$ is a measure of the availability of water in the soil profile and has been used as a good indicator of vine water status in several studies (Santos et al., 2003; Souza et al., 2003; Shultz, 2003; Souza et al., 2005 a, b). However, some authors have demonstrated that $\Psi_{\mathrm{pd}}$ is not in equilibrium with soil water (Garnier \& Berger, 1987, cited by Williams \& Trout, 2005) or may not be the best indicator of the intensity of water stress as compared to $\Psi_{\text {stem }}$ and $\Psi_{\text {md }}$ (Choné et al., 2001; Williams \& Trout, 2005). The $\Psi_{\text {stem }}$ has been considered to be a powerful tool to assess vine water status since it is less affected by short term fluctuations induced by stomatal behaviour and environmental conditions, and may be an accurate indicator for vine irrigation management (Greenspan et al., 1998; Choné et al., 2001).

Although the measurements of $\Psi_{\text {stem }}$ and $\Psi_{\text {md }}$ have not been made at the same time, the treatments were more differentiated by $\Psi_{\text {stem }}$ measured during the morning than $\Psi_{\text {md }}$ measured at midday. Early morning $\Psi_{\text {stem }}$ also allowed a better differentiation between water stress treatments as compared to $\Psi_{\text {stem }}$ and $\Psi_{\text {md }}$ measured at the midday, as shown by Intrigliolo \& Castel (2006). However, the $\Psi_{\text {pd }}$ values were higher than $0,2 \mathrm{MPa}$ in all treatments, a range considered in the literature as absence of water stress (Deloire et al.,
2004). This range was also observed for full irrigated vines as compared to PRD or DI vines (around -0.4 MPa) (Souza et al., 2003; Souza et al, 2005 a, b). On the other hand, the slight decline observed in $\Psi_{\text {pd }}$ of DI vines, where the water was withhold, was probably due to small changes of soil water content at the $0.8,1.0$, and $1.2 \mathrm{~m}$ depths (Figure 1). According to Silva (2005) roots reached the $1.0 \mathrm{~m}$ depth 18 months after planting, i.e., on March 2004. Probably, the soil water uptake was enough to avoid large differences in plant water status between irrigation treatments. Furthermore, the response to irrigation seems to vary with the grapevine variety and with the environmental conditions of a particular year, indicates that differences between water treatments are more relevant under drier conditions (Chaves et al., 2007).

In general terms, the grapevine water status was more affected by rootstock than by irrigation treatment for both cultivars. The better vine water status corresponded to rootstock IAC 572 as revealed by $\Psi_{\text {stem }}$ and $\Psi_{\text {md }}$. Under this condition, the grapevines grafted onto IAC 572 had the highest values of stomatal conductance $\left(g_{s}\right)$ and transpiration rate $(E)$ under both irrigation treatments (Figures $5 \mathrm{a}, \mathrm{b}$, e, f and $6 \mathrm{a}, \mathrm{b}, \mathrm{e}, \mathrm{f}$ ). At the end of the ripening period, after 18 days of soil drying, a significant decrease in $g_{s}$ and $E$ for PRD as compared to DI vines, was shown for Syrah vines onto 1103 Paulsen (Figures $5 \mathrm{c}, \mathrm{d}, \mathrm{g}, \mathrm{h}$ and $6 \mathrm{c}, \mathrm{d}$, g, 


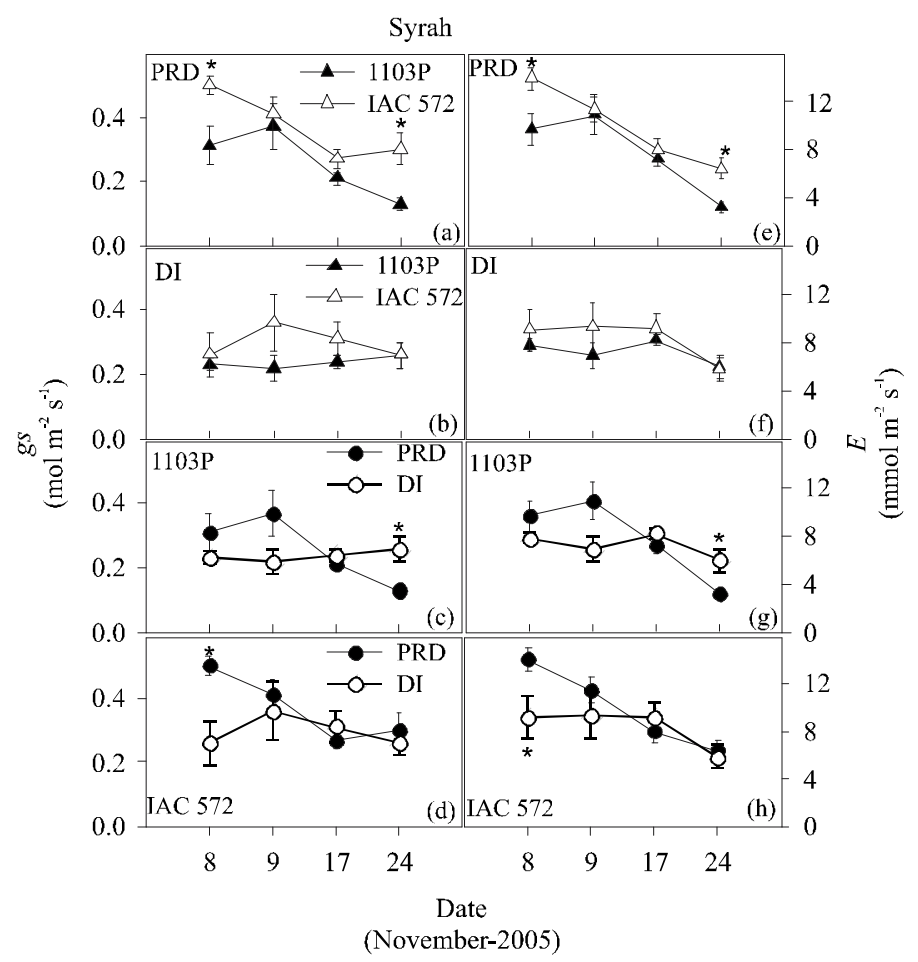

Figure 5 - Effects of rootstock and irrigation treatment on seasonal course of stomatal resistance $\left(r_{s}\right)$ and transpiration $(E)$ measured in Syrah grapevines at midday. Values are means \pm SE. Asterisks mean differences $(p<0.05)$. (PRD = partial rootzone drying; $\mathrm{DI}=$ deficit irrigation.

h). On the other hand, the highest values of $g_{s}$ were shown for Syrah vines onto IAC 572 under PRD as compared to DI conditions. Because it was observed that next to the date of measurements both sides of vines were still wet, it is suggested that these differences were due to the alternation of wet and dry sides (November $7^{\text {th }}$ ) (Figures $5 \mathrm{c}, \mathrm{d}, \mathrm{g}, \mathrm{h}$ ). For Moscato Canelli, there were only differences between rootstocks (Figure 6). For Syrah, differences between rootstocks were only observed under PRD conditions, where the highest $g_{s}$ and $E$ were found for grapevines grafted onto IAC 572 (Figures $5 \mathrm{a}, \mathrm{b}, \mathrm{e}, \mathrm{f}$ ). The different responses to drying soil between rootstock and cultivars can be due to their sensitivity to water stress and/or to the ability of the root system to explore larger volumes of soil increasing water uptake (Carbonneau, 1985).

The high values of $E$ (higher than $8 \mathrm{mmol} \mathrm{m}^{-2} \mathrm{~s}^{-}$ ${ }^{1}$ ) observed for both cultivars (Figures 5 and 6) were due to the high evaporative demand of this region (monthly ETo of 137.2, 155.1, 176.6, and $154.3 \mathrm{~mm}$ in August, September, October, and November 2005). Usually, the values found in the literature range from 1 to $6 \mathrm{mmol} \mathrm{m}^{-2} \mathrm{~s}^{-1}$ for grapevines growing under Mediterranean climate conditions (Shultz, 2003). However, the values $E$ obtained in this study are near to 6 to $13 \mathrm{mmol} \mathrm{m}^{-2} \mathrm{~s}^{-1}$, and are in accordance with those found by Lima Filho (2006) in the same region, using an IRGA.
The greatest differences in leaf specific hydraulic conductance $\left(\mathrm{K}_{\text {leaf }}\right)$ between rootstocks were found for PRD vines of the cultivar Moscato Canelli (Figure 7). $\mathrm{K}_{\text {leaf }}$ of the vines on IAC 572 was higher than those of 1103 Paulsen (Figure 7 a, b, e, f). In most sampling dates, there were no differences between irrigation strategies on leaf specific hydraulic conductance (Figures $7 \mathrm{c}, \mathrm{d}, \mathrm{g}, \mathrm{h}$ ).

The vegetative vigor, indicated by scion leaf area index (LAI), was also more affected by the rootstock than by irrigation treatment (Figure 8). For both cultivars, there was a significant increase in LAI of the scion grafted onto IAC 572 as compared to the vines grafted onto 1103 Paulsen, whereas the irrigation treatments did not affect the vegetative vigor of both cultivars. Although the mechanism for scion vigor control by rootstocks is poorly understood, the differences observed in $g_{s}$ and $\mathrm{K}_{\text {leaf }}$ between the rootstocks (Figures 5, 6, and 7) may help to explain the rootstock effects on scion vigor. The $g_{s}$ and $\mathrm{K}_{\text {leaf }}$ were higher for both cultivars grafted onto IAC 572 than onto 1103 Paulsen. Furthermore, the 1103 Paulsen has been considered as a resistant rootstock to water stress showing a better stomatal control under water deficit conditions (Scienza et al., 1980; Carbonneau, 1985).

Although $E, \mathrm{~K}_{\text {leaf }}$ and $g_{s}$ are not completely independent variables, the decreased stomatal conductance for 1103 Paulsen may be also attributed to the reduced 


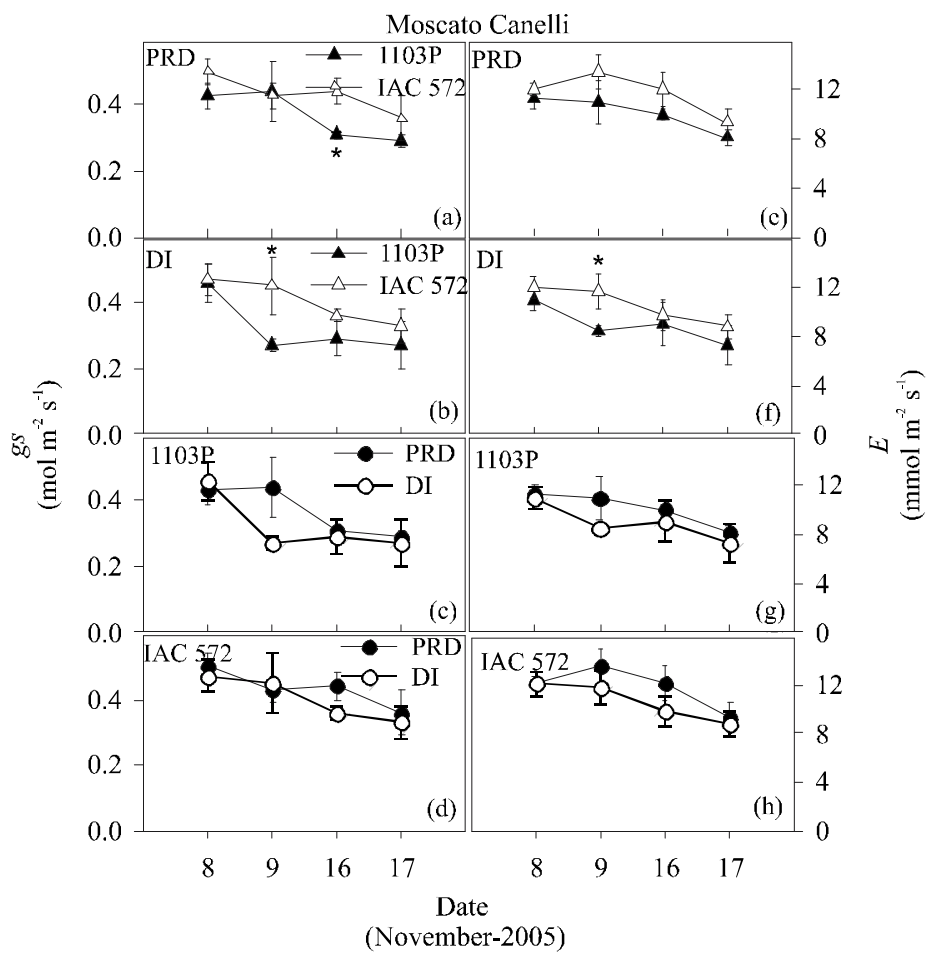

Figure 6 - Effects of rootstock and irrigation treatment on seasonal course of stomatal resistance $(r)$ and transpiration $(E)$ measured for Moscato Canelli grapevines at midday. Values are means \pm SE. Asterisks mean differences $(p<0.05)$. $(\mathrm{PRD}=$ partial rootzone drying; DI = deficit irrigation).

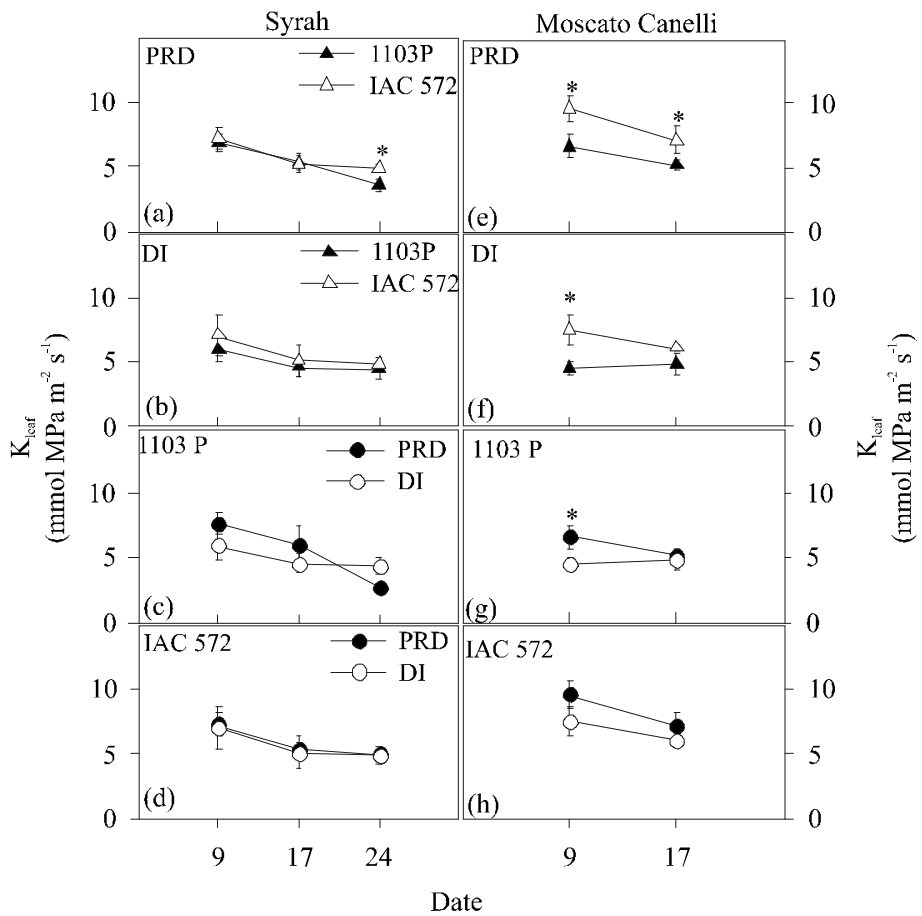

(November -2005)

Figure 7 - Effects of rootstock and irrigation treatment on leaf specific hydraulic conductance $\left(\mathrm{K}_{\text {leaf }}\right)$ of Syrah (a, b, c, d) and Moscato Canelli grapevines $(\mathrm{e}, \mathrm{f}, \mathrm{g}, \mathrm{h})$. Values $\mathrm{K}_{\text {leaf }}$ are means $\pm \mathrm{SE}$. Asterisks mean differences $(p<0.05)$. $(\mathrm{PRD}=$ partial rootzone drying; DI $=$ deficit irrigation). 


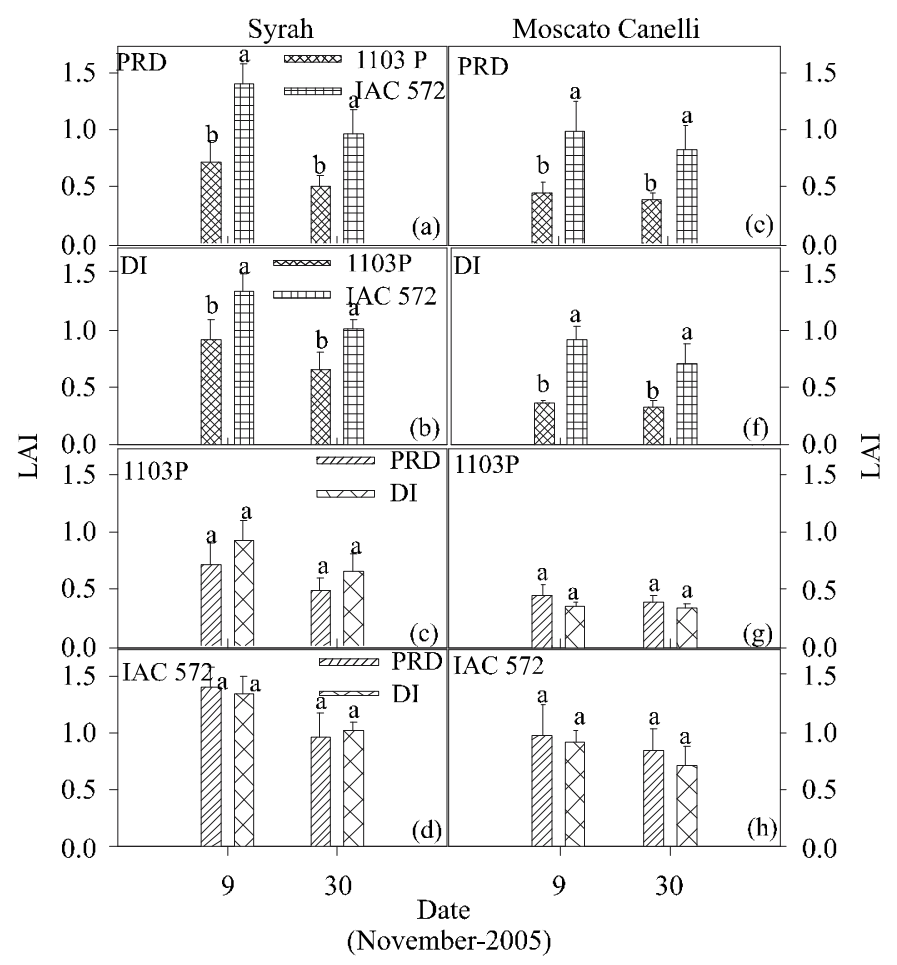

Figure 8 - Effects of rootstock and irrigation treatments on leaf area index (LAI) of Syrah (a, b, c, d) and Moscato Canelli grapevines (e, $\mathrm{f}, \mathrm{g}, \mathrm{h})$. Values are means \pm SE. Asterisks mean differences $(p<0.05)$. (PRD = partial rootzone drying; $\mathrm{DI}=$ deficit irrigation).

$\mathrm{K}_{\text {leaf }}$ observed for this rootstock (Figure 7). Stomata have been found to respond to $\mathrm{K}_{\text {lear }}$, since changes in $\mathrm{K}_{\text {leaf }}$ influence plant water status (Hubbard et al., 2001; Shultz, 2003). On the other hand, the highest values of $\mathrm{K}_{\text {leaf }}$ and $g_{s}$ were measured coinciding with better vine water status as indicated by the $\Psi_{\text {stem }}$ and $\Psi_{\text {md }}$ values (Figure 3 and 4). Therefore, there was an increase of water transport to the shoots, ultimately increasing stomatal conductance and shoot growth. Moreover, the amount of functional xylem tissue in the graft and scion can increase with rootstock vigor (Atkinson et al., 2003). This effect could also explain the increase in $\mathrm{K}_{\text {leaf }}$ and vegetative vigour observed for both cultivars grafted on IAC 572 rootstock.

The scion vigour and water status were stronger affected by rootstock genotype than by irrigation treatments. The rootstock IAC 572 induced more vigour and a better water status of scion than 1103 Paulsen. Rootstocks with low vigour have more positive effects on berry development and ripening than vigorous one (Jackson \& Lombard, 1993; Dry et al., 2001). However, before concluding that high leaf area or production has negative impact on grape quality, it is necessary to define the leaf area required to mature a given amount of fruit without affecting or delaying fruit maturation. Further analyses are being conducted to evaluate the effect of rootstocks and irrigation strategies on grape quality parameters. Un- derstanding the complex interaction between scion and grapevine rootstock, as well as vine water relations and soil water management are essential to optimise the yield and its quality, especially in new wine regions like the São Francisco Valley in Brazil.

Although having found a slight decline in vine water status for both irrigation treatments, the results indicate that for the region under study the vines under PRD showed a better water status than under DI conditions, probably due to high stomatal control regulation shown by PRD vines. The effects of rootstocks on water relations and scion vigour were more pronounced than irrigation treatments. The scion grafted onto rootstock IAC 572 showed high pre-dawn, leaf and stem water potential and higher vigour than scion grafted onto 1103 Paulsen.

\section{ACKNOWLEDGEMENTS}

The financial support provided by 'Banco do Nordeste do Brasil (BNB)' is acknowledged. Claudia Rita de Souza was a recipient of a DCR fellowship granted by $\mathrm{CNPq}$ and Fundação de Apoio à Ciência e Tecnologia do Estado de Pernambuco (FACEPE). The authors also thank Dr Magna Soelma Beserra de Moura (Embrapa Semi-Árido) for meteorological data availability. 


\section{REFERENCES}

ATKINSON, C.J.; ELSE, M.A.; TAYLOR, L.; DOVER, C.J. Root and stem hydraulic conductivity as determinants of growth potential in grafted trees of apple (Malus Pumila Mill.). Journal of Experimental Botany, v.54, p.1221-1229, 2003.

CARBONNEAU, A. The early selection of grapevine rootstocks for resistance to drought conditions. American Journal of Enology and Viticulture, v.36, p.195-198, 1985.

CHAVES, M.C.; SOUZA, C.R.; SANTOS, T.P.; RODRIGUES, M.L.; LOPES, C.M.; MAROCO, J.P.; PEREIRA, J.S. Deficit irrigation in grapevine improves water-use efficiency while controlling vigour and production quality. Annals of Applied Biology, v.150, p.237-252, 2007.

CHONÉ, X.; LEEUWEN C. van; DUBOURDIEU, D.; GAUDILLÈRE, J.P. Stem water potential is a sensitive indicator of grapevine water status. Annals of Botany, v.87, p.477-483, 2001.

DELOIRE, A.; CARBONNEAU, A.; WANG, Z.; OJEDA, H. Vine and water: a short review. Journal International des Sciences de la Vigne et du Vin, v.38, p.1-13, 2004.

DRY, P.R.; LOVEYS, B.R.; McCARTHY, M.G.; STOLL, M. Strategic irrigation management in Australian vineyards. Journal International des Sciences de la Vigne et du Vin, v.35, p.129-139, 2001.

EMPRESA BRASILEIRA DE PESQUISA AGROPECUÁRIA EMBRAPA. Sistema Brasileiro de Classificação de Solos. Rio de Janeiro: Embrapa/CNPS, 1999. 412p.

FERRONI, G; SCALABRELLI. G. Effect of rootstock on vegetative activity and yield in grapevine. Acta Horticulturae, v.388, p.37-42, 1995.

GONÇALVES, C.A.A. Comportamento da cultivar Folha de Figo (Vitis labrusca L) sobre diferentes porta-enxertos de videira. Lavras: Universidade Federal de Lavras, 1996. 45p. Dissertação (Mestrado).

GREENSPAN, M.; SCHULTZ, H.; MATTHEWS, M.A. Field evaluation of water transport in grape berries during water deficits. Physiologia Plantarum, v.97, p.55-62, 1998.

HERRALDE, F; ALSINA, M.M; ARANDA, X.; SAVE, R.; BIEL, C. Effects of rootstock and irrigation regime on hydraulic architetcture of Vitis vinifera L. cv Tempranillo. Journal International des Sciences la Vigne et du Vin, v.40, p.133139,2006

HUBBARD, R.M.; RYAN, M.G.; STILLER, V.; SPERRY, J.S. Stomatal conductance and photosynthesis vary linearly with plant hydraulic conductance in ponderosa pine. Plant, Cell and Environment, v.24, p.113-121, 2001.

IACONO, F; BUCCELA, A.; PETERLUNGER, E. Water stress and rootstock influence on leaf gas exchange of grafted and ungrafted grapevines. Scientia Horticulturae, v.75, p.27-39, 1998.

INTRIGLIOLO, D.S.; CASTEL, J.R. Vine and soil-based measures of water status in a Tempranillo vineyard. Vitis, v.45, p.157163,2006

JACKSON, D.I.; LOMBARD, P.B. Environmental and management practices affecting grape composition and wine quality: a review. American Journal of Enology and Viticulture, v.44, p.409430, 1993.

JOHNSON, L.F.; PIERCE, L.L. Indirect measurement leaf area index in California North Coast vineyards. HortScience, v.39, p.236-238, 2004.

KASERER, H.; BLAHOUS, D.; BRANDES, W. Optimizing wine grape quality by considering rootstock-scion interaction. Acta Horticulturae, v.427, p.267-275, 1996.

KELLER, J.; BLIESNER, R.D. Sprinkle and trickle irrigation. Caldwell: Blackburn Press, 2000. 584p.

KOBLET, W.; CANDOLFI-VASCONCELOS, M.C.; KELLER, M. Effects of training system, canopy management practices, crop load and rootstock on grapevine photosynthesis. Acta Horticulturae, v.427, p.133-139, 1997
KOBLET, W.; CANDOLFI-VASCONCELOS, M.C.; ZWEIFEL, W.; HOWELL, G.S. Influence of leaf removal, rootstock, and training system on yield and fruit composition of Pinot Noir grapevines. American Journal of Enology and Viticulture, v.45, p.180187,1994

LIMA FILHO, J.M.; BASSOI, L.H.; DANTAS, B.F. Determinação do índice de área foliar da videira conduzida em espaldeira, com o analisador de dossel LI-2000. In: CONGRESSO BRASILEIRO DE FRUTICUlTURA, 19., Cabo Frio, 2006. Anais. Cabo Frio, SBF/UENF/UFRRJ, 2006. p.361.

LOVEYS, B.R.; DRY, P.R.; STOLL, M.; McCARTHY, M.G. Using plant physiology to improve the water use efficiency of horticultural crops. Acta Horticulturae, v.537, p.187-199, 2000.

MAIN, G.; MORRIS, J.; STRIEGLER, K. Rootstock effects on Chardonel productivity, fruit and wine composition. American Journal of Enology and Viticulture, v.53, p.37-40, 2002.

McCARTHY, M.G. The effect of transient water deficit on berry development of Shyraz Vitis Vinifera L. Australian Journal of Grape and Wine Research, v.3, p.102-108, 1997.

MORANO, L.; KLIWER, W.M. Root distribution of three grapevines rootstocks grafted to Cabernet Sauvignon grown on a very gravelly clay loam soil in Oakville, California. American Journal of Enology and Viticulture, v.45, p.345-348, 1994.

OLLAT, N.; FERMAUD, M.; TANDONNET, J.P.; NEVEUX, M. Evaluation of an indirect method for leaf area index determination in the vineyard: Combined effects of cultivar, year and training system. Vitis, v.37, p.73-78, 1998.

PARANYCHIANAKIS, N.V.; ANGGELIDES, S.; ANGELAKIS, A.N. Influence of rootstock, irrigation level and recycled water on growth and yield of Soultanina grapevines. Agricultural Water Management, v.69, p.13-27, 2004.

PAULETTO, D.; MOURÃO FILHO, F.A.A.; KLUGE, R.A.; SCARPARE FILHO, J.A. Efeito do porta-enxerto na qualidade do cacho da videira 'Niagara Rosada'. Pesquisa Agropecuária Brasileira, v.36, p.935-939, 2001a.

PAULETTO, D.; MOURÃO FILHO, F.A.A.; KLUGE, R.A.; SCARPARE FILHO, J.A. Produção e vigour da videira 'Niágara Rosada' relacionados com o porta-enxerto. Pesquisa Agropecuária Brasileira, v.36, p.115-121, 2001 b.

SANTOS, T.P.; LOPES, C.M.; RODRIGUES, M.L.; SOUZA, C.R.; MAROCO, J.P.; PEREIRA, J.S.; SILVA, J.M.R.; CHAVES, M.M. Partial rootzone drying: effects on growth and fruit quality of field-grown grapevines (Vitis vinifera). Functional Plant Biology, v.30, p.663-671, 2003.

SCIENZA, A.; FREGONI, M.; BOSELLI, M. Influenza del portinnesto sulla resistenza stomatica, sul potenziale hídrico e sul contenuto di acido abscissico di foglie di 'Barbera'. Vignevine, v.1, p.39-44, 1980.

SILVA, J.A.M. Irrigação lateralmente alternada e com déficit controlado na videira cv. Petite Syrah. Viçosa: UFV, 2005. 92p. Dissertação (Mestrado).

SILVA, M.S.L. Caracterização e gênese do adensamento subsuperficial em solos do Tabuleiro do Semi-Árido do Nordeste do Brasil. Porto Alegre: UFRGS, 2000. 126p. Tese (Doutorado)

SOUZA, C.R.; MAROCO, J.P.; SANTOS, T.; RODRIGUES, M.L.; LOPES, C.; PEREIRA, J.S.; CHAVES, M.M. Partial rootzone drying: regulation of stomatal aperture and carbon assimilation in field grown grapevines (Vitis vinifera). Functional Plant Biology, v.30, p.653-662, 2003.

SOUZA, C.R.; MAROCO, J.P.; SANTOS, T.; RODRIGUES, M.L.; LOPES, C.; PEREIRA, J.S.; CHAVES, M.M. Control of stomatal aperture and carbon uptake by deficit irrigation in two grapevine cultivars. Agriculture Ecosystem and Environment, v.106, p.261-274, 2005a.

SOUZA, C.R.; MAROCO, J.P.; SANTOS, T.; RODRIGUES, M.L.; LOPES, C.; PEREIRA, J.S.; CHAVES, M.M. Impact of deficit irrigation on water use efficiency and carbon isotope composition $\left(\delta^{13} \mathrm{C}\right)$ of field-grown grapevines under Mediterranean climate. Journal of Experimental Botany, v.56, p. 2163-2172, 2005 b. 
STOLL, M.; LOVEYS, B.; DRY, P. Hormonal changes induced by partial rootzone drying of irrigated grapevine. Journal of Experimental Botany, v.51, p.1627-1634, 2000.

TEIXEIRA, A.H.C. Informações Agrometeorológicas do Pólo Petrolina-PE/Juazeiro-BA. Petrolina: Embrapa Semi-Árido, 2001. 48p. (Documentos. Embrapa Semi-Árido).

TERRA, M.M.; PIRES, E.J.P.; POMMER, C.V.; BOTELLO, R.V. Produtividade da cultivar de uva de mesa Niágara Rosada sobre diferentes porta-enxertos, em Monte Alegre do Sul-SP. Revista Brasileira de Fruticultura, v.25, p.549-551, 2003.

TOUMI, I.; M'SEHLI, W.; BOURGOU, S.; JALLOULI, N.; BENSALEM-FNAYOU, A.; GHORBEL, A.; MLIKI, A Response of ungrafted and grafted grapevine cultivars and rootstocks (Vitis sp.) to water stress. Journal International des Sciences la Vigne et du Vin, v.41, p.85-93, 2007.
WELLES, J.M.; NORMAN, J.M. Instrument for indirect measurement of canopy architecture. Agronomy Journal, v.83, p.818-825, 1991 .

WILLIAMS, L.E. TROUT, T. Relationships among vine- and soilbased measures of water status in a Thompson Seedless vineyard in response to high frequency drip irrigation. American Journal of Enology and Viticulture, v.56, p.357-366, 2005.

Received July 16, 2007

Accepted February 16, 2008 